\title{
SUPERVISI PENDIDIKAN DALAM MENINGKATKAN \\ KUALITAS PENDIDIKAN
}

\author{
Oleh \\ Septia Wulandari \\ Email : septiawulandari22011999@gmail.com
}

\begin{abstract}
Abstrak
Kualitas pembelajaran di sekolah sangat dipengaruhi oleh guru. Oleh karena itu sangat diperlukan peran supervisor dalam meningkatkan kualitas seorang guru. Kegiatan supervisi harus dilakukan secara terus menurus agar tercapainya hasil yang di inginkan yaitu menghasilkan guru yang profesional. Supervisi dapat dilaksanakan melalui teknik kunjungan kelas, wawancara, angket, dan laporan. Teknik yang biasa digunakan adalah kunjungan kelas ketika guru sedang mengajar didepan kelas. Seorang supervisor bertugas untuk membantu, membimbing dan membina guru agar dapat memperbaiki proses kinerjanya sehingga menjadi guru yang profesional. Guru yang profesional akan mengasilkan mutu pendidikan yang baik. Guru yang profesional harus memiliki empat kompetensi yaitu yang pertama seorang guru harus memiliki kepribadian yang mantap,arif, dan bijaksana. Yang kedua seorang guru harus memiliki kompetensi pendagogik yakni maтри memahami peserta didik, mampu merencanakan, melaksanakan, mengevaluasi serta mengembangkan pembelajaran. Yang ketiga profesional, dimana guru menguasai substansi keilmuannya. Dan yang terakhir sosial, yakni kemampuan komunikasi yang baik. Jika seorang guru memiliki ke empat kompetensi di atas maka akan menghasilkan pembelajaran yang berkualitas.
\end{abstract}

Kata kunci : kualitas pembelajaran, peran supervisor, guru yang profesional.

\section{PENDAHULUAN}

\section{Latar Belakang}

Kepala sekolah dalam pelaksanaan supervisi bukan hanya bertugas menilai kinerja guru saja, tetapi juga menilai semua kegiatan yang berhubungan dengan proses pembelajaran. Hal ini didukung oleh Glickman (1981 : 34), yang mengatakan supervisi akademik adalah serangkaian kegiatan membantu guru mengembangkan kemampuannya mengelola proses belajar mengajar demi pencapaian tujuan pengajaran.

Dalam Undang -Undang Sistem Pendidikan Nasional Tahun 2003 disebutkan bahwa guru harus memiliki 4 kompetensi yaitu (1) kepribadian, (2) pedagogik, (3) profesional, dan (4) sosial. Tetapi tidak semua guru memiliki kompetensi tersebut, hal ini dilihat dari banyaknya guru-guru yang tidak dapat menjalankan tugasnya dengan baik, dalam perencanaan maupun pelaksanaan proses pembelajaran di sekolah, sehingga terdapat perbedaan hasil atau kualitas pendidikan yang dihasilkan oleh setiap guru. 
Kenyataan yang terjadi di lapangan pelaksanaan supervisi oleh kepala sekolah kurang terlaksana. Hal ini bisa kita lihat masih banyak guru-guru yang tidak bisa meningkatkan kualitas dan prestasi kerjanya, ini sangat mengganggu proses pembelajaran di sekolah. Selain itu permasalahan yang terjadi adalah masih rendahnya kualitas kepala sekolah dalam pelaksanaan supervisi terhadap guru, faktor yang menyebabkan kesukaran kepala sekolah dalam pelaksanaan supervisi seperti yang diungkapkan oleh (Imran 1995:99) yang mengatakan terbatasnya kemampuan profesional, terbatasnya waktu, terbatasnya petunjuk pelaksanaan dan terbatasnya biaya".

Dari latar belakang diatas rumusan masalahnya adalah (1) apa saja peran kepala sekolah sebagai supervisor ? dan (2) bagaimana seorang guru yang profesional itu ?

Tujuan dari penulisan artikel ini yaitu (1) untuk mengetahui peran kepala sekolah sebagai supervisor, dan (2) untuk mengetahui seperti apa guru yang profesional itu.

\section{PEMBAHASAN}

\section{Kepala Sekolah sebagai Supervisor}

Supervisor memegang peranan penting dalam meningkatkan kualitas guru agar dapat melaksanakan pembelajaran yang lebih berkualitas. Yang menjadi supervisor di sekolah yaitu kepala sekolah dan pengawas. Supervisi yang dilakukan oleh kepala sekolah diatur dalam Permen Diknas Nomor 13 Tahun 2007 tentang Standar Kepala Sekolah/Madrasah. Dimensi kompetensi supervisi kepala sekolah yang meliputi: (1) merencanakan program supervisi akademik dalam rangka peningkatan profesionalisme guru, (2) melaksanakan supervisi akademik terhadap guru dengan menggunakan pendekatan dan teknik supervisi yang tepat, dan (3) menindaklanjuti hasil supervisi akademik terhadap guru dalam rangka peningkatan profesionalisme guru.

Kepala Sekolah sebagai penanggung jawab pendidikan memiliki tugas utama untuk melaksanakan kegiatan supervisi akademik di sekolah. Pada umumnya, kegiatan supervisi akademik yang paling mudah dan sering dilakukan oleh Kepala Sekolah adalah supervisi akademik dengan teknik kunjungan pada saat guru mengajar di kelas.

\section{Guru yang Profesional}

Guru yang profesional sangat penting untuk meningkatkan mutu pendidikan sekolah. Untuk menjadi guru yang profesional, seorang guru dituntut memiliki lima hal, yaitu :

a. Guru mempunyai komitmen pada siswa dan proses belajarnya. Ini berarti komitmen tertinggi guru adalah kepada kepentingan siswanya.

b. Guru menguasai secara mendalam bahan/ mata pelajaran yang diajarkan serta cara mengajarkannya kepada siswa. Bagi guru, hal ini merupakan dua hal yang tidak dapat dipisahkan.

c. Guru bertanggung jawab memantau hasil belajar siswa melalui berbagai teknik evaluasi, mulai cara pengamatan dalam perilaku siswa sampai tes hasil belajar.

d. Guru mampu berpikir sistematis tentang apa yang dilakukannya, dan belajar dari pengalamannya. Artinya, harus selalu ada waktu untuk guru mengadakan refleksi dan koreksi terhadap apa yang telah dilakukannya. Untuk bisa belajar dari pengalaman, ia harus tahu mana yang benar dan yang salah, serta baik buruk dampaknya pada proses belajar siswa.

e. Guru seyogianya merupakan bagian dari masyarakat belajar dalam lingkungan profesinya, misalnya PGRI dan organisasi profesi lainnya (Supriadi, 1999:98). 
Selain memiliki lima hal diatas seorang guru juga harus memiliki empat kompetensi yaitu pertama kepribadian yang mantap, arif, bijaksana. Kedua pendagogik yakni mampu memahami peserta didik, mampu merencanakan, melaksanakan, mengevaluasi serta mengembangkan pembelajaran. Yang ketiga profesional, dimana guru menguasai substansi keilmuannya. Dan yang terakhir sosial, yakni kemampuan komunikasi yang baik.

\section{PENUTUP}

\section{Kesimpulan}

Berdasarkan pembahasan diatas dapat disimpulkan bahwa seorang supervisor sangat berperan dalam menghasilkan guru yang profesional. Salah satu supervisor adalah kepala sekolah, kegiatan yang paling mudah dan sering dilakukan oleh Kepala Sekolah adalah supervisi akademik dengan teknik kunjungan kelas pada saat guru mengajar di kelas.

Seorang guru harus profesional dalam mengajar agar menghasilkan mutu pendidikan yang berkualitas. Guru yang profesional memiliki empat kompetensi yang pertama kepribadian yang mantap, arif, bijaksana. Kedua pendagogik yakni mampu memahami peserta didik, mampu merencanakan, melaksanakan, mengevaluasi serta mengembangkan pembelajaran. Yang ketiga profesional, dimana guru menguasai substansi keilmuannya. Dan yang terakhir sosial, yakni kemampuan komunikasi yang baik.

\section{Saran}

Agar pendidikan di Indonesia memiliki kualitas yang tinggi maka seorang supervisor harus melaksanakan tugasnya dengan baik. Dan para guru juga harus melaksanakan apa yang disarankan oleh supervisor. Guru harus menguasai empat kompetensi guru profesional (kepribadian, pendagogik, profesional, dan sosial) agar mutu pendidikan terjamin.

\section{DAFTAR PUSTAKA}

Maralih, Maralih. "PERANAN SUPERVISI DALAM PENINGKATAN KUALITAS PENDIDIKAN." QATHRUNÂ 1.01 (2017): 179-192.

Sabandi, Ahmad. "Supervisi Pendidikan Untuk Pengembangan Profesionalitas Guru Berkelanjutan." Pedagogi: Jurnal Ilmu Pendidikan 13.2 (2013): 1-9.

Kadarwati, Ani. "PENINGKATAN KUALITAS PEMBELAJARAN MELALUI SUPERVISI AKADEMIKDENGAN TEKNIK KUNJUNGAN KELAS." Gulawentah: Jurnal Studi Sosial 1.2 (2016): 103-12.

Rohmatika, Ratu Vina. MODEL SUPERVISI KLINIS TERPADU UNTUK PENINGKATAN KINERJA GURU MADRASAH ALIYAH. Diss. IAIN Raden Intan Lampung, 2017.

Giri, I. Made Ariasa. "SUPERVISI PENDIDIKAN DALAM PENINGKATAN MUTU PENDIDIKAN DI SEKOLAH." Jurnal Penjaminan Mutu 2.1 (2016): 44-53. 